\title{
Časoprostorová dynamika vnosu organických látek do vodárenské nádrže Švihov
}

\section{TOMÁŠ MIČANÍK, FRANTIŠEK SÝKORA, DAVID CHRASTINA, NIKOLA CIELECKÁ, VERONIKA KUCHARCZYKOVÁ, ALENA KRISTOVÁ, TOMÁŠ OCELKA, JIŘí OCEÁNSKÝ}

Klíčová slova: povrchová voda - pasivní vzorkování - vodárenská nádrž Švihov - znečištění - pesticidy

\section{SOUHRN}

Tento příspěvek se věnuje dynamice vnosu nepolárních organických látek a polárních pesticidů do vodárenské nádrže Švihov v povodí Želivky během celé vegetační sezony pomocí pasivních vzorkovačủ. Monitoring probíhal od dubna do listopadu 2018 na devíti prítocích do VN Švihov a na vstupu surové vody do ÚV Želivka, a. s. Pro záchyt širokého spektra látek bylo použito více typů membrán: SR (měřeno 61 látek), SPMD (měřeno 43 látek) a POCIS (měřeno 38 látek). Doba jejich expozice ve vodě činila 30 dní. Během pasivního monitoringu byly zaznamenávány srážko-odtokové poměry z on-line dostupných měricích stanic $v$ povodí Želivky.

$\checkmark$ prítocích do VN Švihov bylo pasivním monitoringem identifikováno přes 80 organických látek. Z nepolárních organických látek byla potvrzena trvalá prítomnost již dávno nepouživaných organochlorových pesticidů HCH a DDT. Poměr zastoupených kongenerů PCB odpovídá dřivějšímu používání výrobků obsahujících Delor 106. Výskyt pesticidů v membránách odpovídal druhové skladbě pěstovaných zemědělských plodin v povodí jednotlivých prítoků. Míra znečištění vod závisela významně na srážko-odtokových poměrech, erozi půdy a charakteru dílčích povodí. K nejvíce znečištěným prítokům náleží Medulán a Lohenický potok. $V$ prípadě některých pesticidů převažoval obsah metabolitů nad mateřskou látkou. Nejvyšší obsahy v membránách byly zaznamenány v př́ipadě metazachloru (max. 19000 ng/membránu), metolachloru (max. 1300 ng/ membránu) a terbuthylazinu-2-hydroxy (max. 1800 ng/membránu), z nepolárních látek fluoranthenu (683 ng/membránu).

\section{ÚVOD}

Tento článek představuje výsledky řešení projektu Čistá voda - zdravé město, Konceptu I: „Studie vnosu pesticidů do vodárenské nádrže Švihov (Želivka) s využitím nových vzorkovacích technik a odstranění organických látek ze sorpčních filtrů za ozonizací vysoce-účinnou chemickou destrukcí a je zaměřen na dynamiku vnosu organických látek vybranými přitoky do vodárenské nádrže Švihov.

Vodárenské dílo Švihov (dále VN Švihov) v povodí řeky Želivky je z hlediska objemu povrchové vody v zásobním prostoru i z pohledu odebíraného množství pro úpravu na vodu pitnou nejvýznamnějším vodárenským zdrojem v České republice. Pitnou vodou z úpravny vody Želivka, a. s., je zásobováno obyvatelstvo hlavního města Prahy, středočeské oblasti a části jihočeské a východočeské oblasti v objemu až do výše $5,25 \mathrm{~m}^{3} / \mathrm{s}$ [1]. Plocha povodí k hrázi vodárenské nádrže činí 1178 km² a zasahuje na území tři krajů a šesti okresů. Území je významně ovlivněno zemědělskou činností, orná pưda činí téměř polovinu celkové plochy povodí. Povodí kolem VN Švihov je zastavěno lidskými sídly převážně vesnického charakteru. Zemědělsky obhospodařované plochy se nacházejí i kolem vlastní VN Švihov, zvláště na straně levostranných př́toků do nádrže, kde plocha povodí je několikanásobně větší než u pravostranných př́toků. Pěstební činnost je z významné části své plochy prováděna na svažitých pozemcích nezrídka až na samou hranici lesního porostu a v některých prípadech až k hranici ochranného pásma vodního zdroje I. stupně. Hlavním a hydrologicky nejvýznamnějším přítokem do vodárenské nádrže je řeka Želivka.

Dlouhodobým monitoringem správce tohoto povodí (Povodí Vltavy, s. p.) je potvrzeno, že prípravky na ochranu rostlin se povrchovou erozí i podzemními vodami dostávají do vodních toků a do soustavy vodních nádrží v povodí Želivky včetně vN Švihov [2, 3]. To je dáno jak fyzikálně-chemickými vlastnosti jednotlivých složek rostlinolékařských přípravků (rozpustnost ve vodě, přítomnost smáčedel pro snižení povrchového napětí kapaliny), tak i morfologií terénu (půdní a větrná eroze), druhovou skladbou zemědělských plodin a klimatickými vlivy (srážko-odtokovými poměry).

Řešení projektu Čistá voda - zdravé město, Koncept I bylo zaměřeno na studium vnosu polárních a nepolárních organických látek vybranými nejvýznamnějšími přítoky do VN Švihov. Jedním z hlavních cílů Konceptu I bylo zvýšení úrovně poznání o časoprostorovém vnosu pesticidů do VN Švihov pomocí tzv. pasivních vzorkovačů. Ty byly aplikovány po celou dobu jedné vegetační sezony od dubna do listopadu 2018. Vzorky exponovaných membrán ze vzorkovačů byly analyticky zpracovány. Po celou dobu pasivního monitoringu byla zaznamenávána a následně zpracovávána on-line dostupná klimatologická a hydrologická data ze stanic nacházejících se v povodí Želivky (v denním a hodinovém kroku).

\section{METODY PASIVNÍHO MONITORINGU POVRCHOVÝCH VOD}

\section{Výběr lokalit}

Pro pasivní monitoring bylo vybráno celkem devět př́toků do VN Švihov: páteřní tok Želivka, sedm levostranných a jeden pravostranný př́tok. Jako poslední monitorovací bod byl zvolen nátok surové vody $v$ rozdělovacím objektu úv Želivka. Rekognoskací terénu během první vzorkovací kampaně byla vybrána vhodná místa pro aplikaci pasivních vzorkovačů tak, aby jejich ponoření ve vodě bylo zajištěno i v letních měsících při výrazně nižších průtocích a zároveň aby nebyla nápadná a bylo minimalizováno riziko neoprávněné manipulace nebo zcizení vzorkovačů. Lokalizace vzorkovacích míst je znázorněna na obr. 1. 


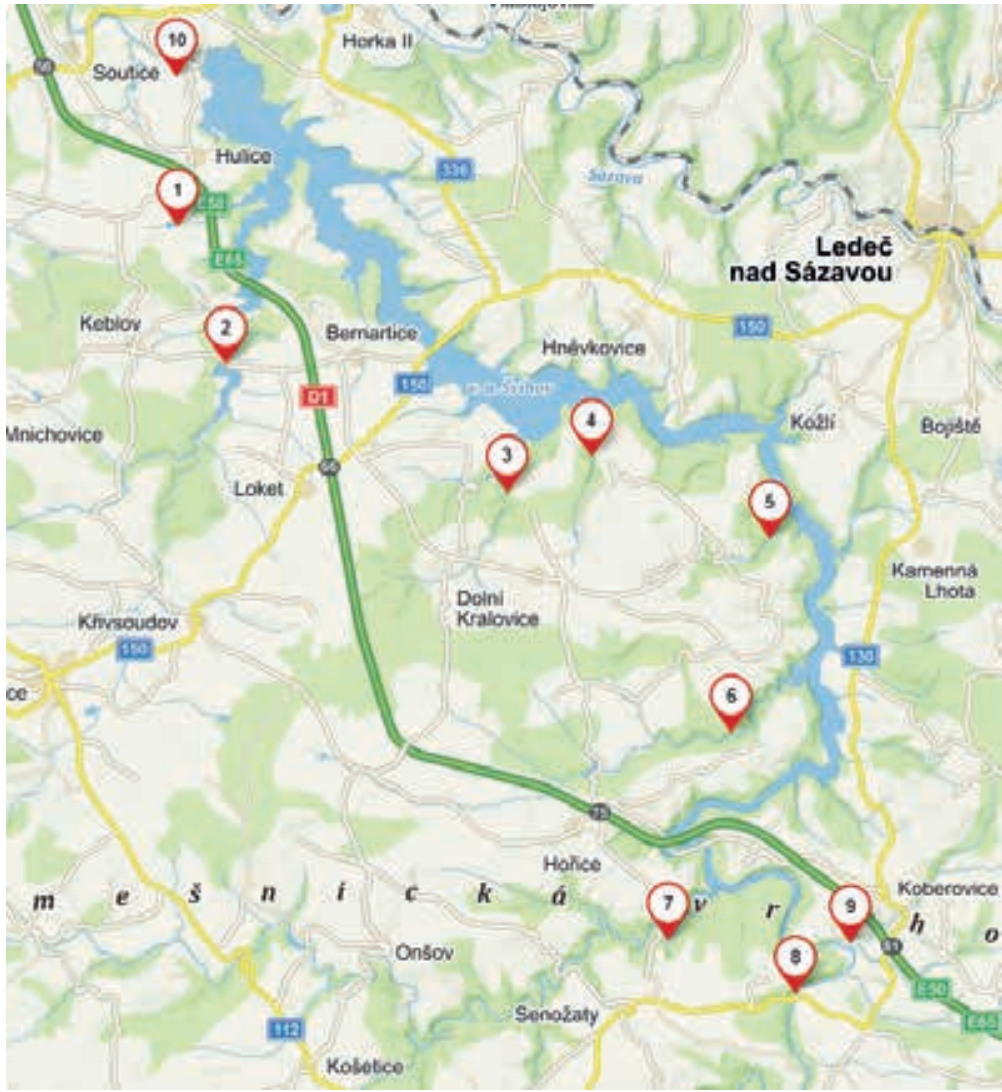

Obr. 1. Lokalizace profilů na prítocích do VN Švihov pro pasivní vzorkování

Fig. 1. Monitoring sites on tributaries around WR Švihov used for passive sampling

Popis lokalit je uveden v tabulce 1. První vzorkovací kampaň byla zahájena 3. dubna 2018. Doba expozice membrán činila v průměru 30 dní (28 až 32 dní). Při každé následující vzorkovací kampani byly nejprve deinstalovány membrány z předchozí vzorkovací kampaně a instalovány membrány nové. Celkem proběhlo osm vzorkovacích kampaní. Poslední expozice byla ukončena 3. prosince 2018.

Ukázka lokalit s umístěnými pasivními vzorkovači je na obr.2.
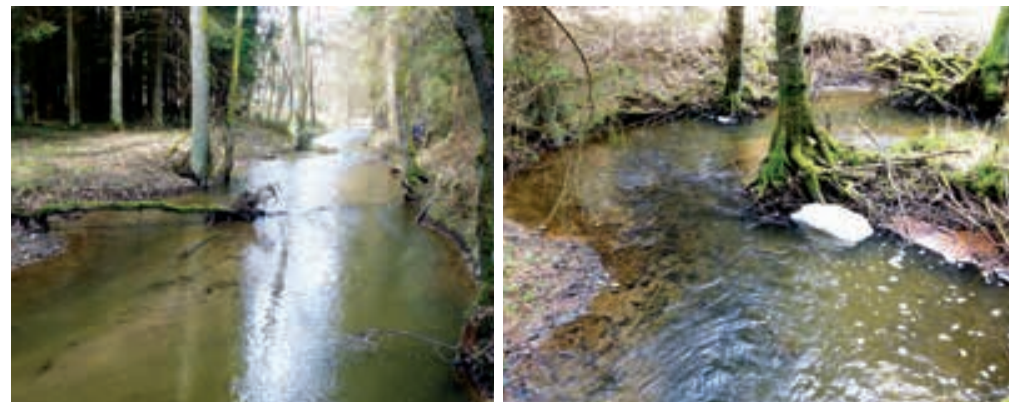

Obr. 2. Lokalita č. 6 a 7

Fig. 2. Sampling site No. 6 and 7

\section{Výběr polutantů a typů membrán}

Důležitým krokem řešení bylo zaměřit se na pesticidy, které se v povodí Želivky jeví jako nejvíce relevantní. Jedním ze zdrojů dat byla evidence spotřeb účinných látek rostlinolékařských prípravků vedená Ústředním kontrolním a zkušebním ústavem zemědělským (ÚKZÚZ) v jednotlivých okresech v povodí Želivky [4]. Dalším zdrojem dat byla rešerše publikovaných výsledků aktivit správce Povodí Vltavy, s. p. [2, 3]. Bylo vybráno celkem 38 pesticidů (včetně metabolitů), které byly v povrchových vodách nacházeny s nejvyšší četností nebo ve významných koncentracích a tři organické látky, které se $v$ povrchových vodách v povodí Želivky trvale vyskytují (DEET, benzotriazol a benzotriazol-methyl). Glyfosát a AMPA byly do pasivního monitoringu zařazeny vzhledem $\mathrm{k}$ současné celoevropské diskusi ohledně jejich možného rizika pro zdraví člověka [5-7]. Vzhledem k tomu, že se jedná o polární látky, byly pro pasivní monitoring zvoleny vzorkovače typu POCIS (Polar Organic Compound Integrative Sampler), a to typ POCIS-Pes a v menší míře POCIS-Pharm. Pro záchyt silně polárního glyfosátu a jeho metabolitu AMPA byl použit POCIS-Glyphosate.

Pasivní monitoring se zaměřil také na nepolární látky, které se do povrchových vod dostávají také komunálními odpadními vodami a atmosférickou depozicí. Jedná se o organochlorové pesticidy (OCP), polycyklické aromatické uhlovodíky (PAU), polychlorované bifenyly (PCB) a chlorbenzeny (CB). Tyto látky byly monitorovány pomocí tzv. SPMD membrán (SemiPermeabile Membrane Device) obsahujících PRC a souběžně s nimi byly použity SR membrány (Silicone Rubber). Přehled vzorkovacích kampaní a typů nasazených membrán je uveden v tabulce 2 .

Tabulka 1. Popis vzorkovacích lokalit

Table 1. Sampling sites specification

\begin{tabular}{|c|c|c|c|c|}
\hline Č. & Název toku & Délka toku [km] & Lokalizace profilu & Ř. $\mathbf{k m}$ \\
\hline 1 & Medulán & 2,5 & pod rybníkem & 1,88 \\
\hline 2 & Sedlický p. & 23,6 & u hráze VN Němčice & 6,91 \\
\hline 3 & Tomický p. & 6,45 & mezi ústím a místní komunikací & 2,12 \\
\hline 4 & Zahrádčický p. & 4,0 & pod obcí Zahrádčice & 0,9 \\
\hline 5 & Šetějovický p. & 4,0 & ústí & 0,95 \\
\hline 6 & Blažejovický p. & 14,05 & cca 1,3 km pod Šálkovým mlýnem & 1,97 \\
\hline 7 & Martinický p. & 38,4 & pod limnigrafem u Jankovského Mlýna & 2,2 \\
\hline 8 & Želivka-Miletín & 104 & pod křížením toku se státní silnicí č. 130 & 42,8 \\
\hline 9 & Lohenický p. & 3,9 & ústí u Bělského Dvoru & 0,1 \\
\hline 10 & úV Želivka surová voda & - & nátok v rozdělovacím objektu úv Želivka & - \\
\hline
\end{tabular}




\section{Pasivní vzorkování vod}

Pasivní vzorkování je poměrně novou technikou monitorování vod založenou na záchytu polutantů pomocí membrán, které podle použitých materiálů a/nebo sorbentů zachytávají z okolního prostředí specifickou skupinu látek [8]. Vzhledem k tomu, že doba jejich expozice je několik dní až týdnů, může tato vzorkovací technika podchytit náhodné emise do prostředí. Proto je vhodná pro záchyt pesticidů, které jsou do vod vyplavovány v závislosti na době jejich aplikace, chodu a intenzitě srážek.

Membrány byly na lokalitách č. 1 a 2 aplikovány v koších, na ostatních lokalitách v podlouhlých úzkých koších, aby se při nízkých průtocích snížilo riziko jejich vynoření (a tím znehodnocení). Do jednoho podlouhlého koše je možné vložit dvě membrány (1×SR + 1× SPMD) nebo jednu až tři membrány POCIS mini. Ukázky jsou na obr. 3.
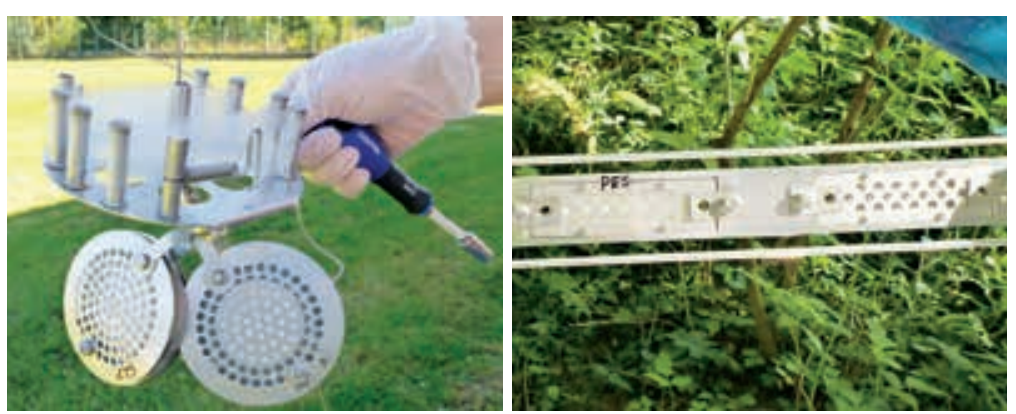

Obr. 3. Membrány: SR (vlevo nahoře), POCIS (vlevo dole), POCIS mini (vpravo) Fig. 3. Membranes: SR (left up), POCIS (left down), POCIS mini (right)

Během manipulace s SPMD a SR membránami (při jejich vyjmutí z transportního obalu a při manipulaci s nimi) byly exponovány tzv. transportní blanky, v každé kampani $1 \times$ SPMD a $1 \times$ SR pro kontrolu, zda během nasazování membrán do držáků nedochází k jejich kontaminaci z okolního prostředí. $\checkmark$ každé kampani byly vždy na jedné z deseti lokalit všechny typy aplikovaných membrán zdvojeny. Vzhledem k tomu, že jsme se $v$ počátečních vzorkovacích kampaních ojediněle setkali s okusováním SPMD membrán, byly tyto vloženy do stahovací ochranné sítky s velikostí mřížky 500 mikronů. Na lokalitách, kde se tento problém nevyskytl, nebylo potřeba vzorkovací koše takto chránit. Po celou dobu jsme se nesetkali s problémem vandalismu nebo odcizení vzorkovacích košů. Pouze v jednom prípadě na lokalitě č. 5 (Zahrádčický potok) došlo při přívalovém dešti enormní intenzity k utržení dvou vzorkovacích košů, kdy jeden zůstal ponořen ve vodě, druhý nebyl nalezen. Ukázka exponovaných membrán je na obr. 4.

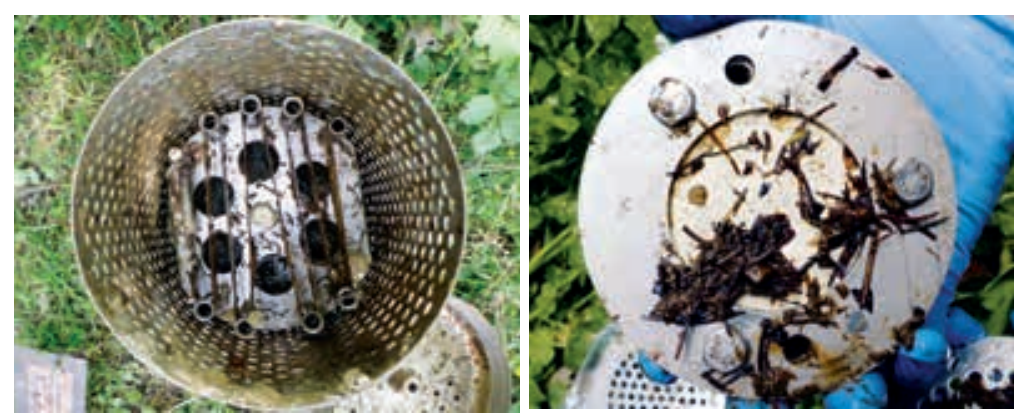

Obr. 4. Exponované membrány: SR (vlevo), POCIS (vpravo)

Fig. 4. Membranes: SR (left), POCIS (right)

\section{Organická stopová analýza}

Exponované membrány před jejich zpracováním byly skladovány při teplotě $-20{ }^{\circ} \mathrm{C}$. Následně byly postupně zpracovávány podle jejich druhu. Nepolární organické látky byly z membrán SPMD extrahovány organickým rozpouštědlem (hexan). Extrakty byly zahuštěny pomocí rotační vakuové odparky a čištěny metodou gelové permeační chromatografie na sestavě YL9100 s DAD detektorem a děličem frakcí. Získané eluáty byly zakoncentrovány a rozděleny na dva alikvótní podíly pro stanovení PAU a pro stanovení PCB, OCP a CB. Po prevedení vzorků do vhodného rozpouštědla byly PAU analyzovány pomocí HPLCFLD. PCB, OCP a CB byly analyzovány na GC s vysokoteplotním ECD. Vnitřní kontrola byla zajištěna přídavkem interního standardu ke zpracovávaným vzorkům. Naměřené hodnoty jednotlivých analytů byly přepočteny na výtěžnost extrakce. Silikonové membrány byly očištěny od nánosů ze vzorkování a extrahovány $2 \times 24$ hodin methanolem s isotopicky značenými standardy. V závislosti na druhu analytů byl extrakt zahuštěn na požadovaný objem a rozdělen pro jednotlivé analýzy PBDE, PCB, OCP a PAU pomocí GC-MS/MS a HPLC-FLD. Meze stanovitelnosti použitých analytických metod pro jednotlivé nepolární organické látky v nanogramech na membránu jsou uvedeny v tabulce 3.

Tabulka 2. Vzorkovací kampaně a druhy instalovaných membrán

Table 2. Passive sampling campaigns and types of membranes

\section{Druhy membrán}

\begin{tabular}{|c|c|c|c|c|c|c|}
\hline \multirow[b]{2}{*}{ Kampaň } & \multirow[b]{2}{*}{ Expozice } & \multirow[b]{2}{*}{ Instalace } & \multirow[b]{2}{*}{ SPMD } & \\
\hline & & & & $\begin{array}{l}\text { POCIS-Pharm } \\
\text { POCIS-Pes* }\end{array}$ & POCIS-Gly & SR \\
\hline 1 & dubnová & 3.-4. 4. 2018 & $x$ & $x^{*}$ & & \\
\hline 2 & květnová & 3.-4. 5. 2018 & & $X^{*}$ & & $x$ \\
\hline 3 & červnová & 4.-5. 6. 2018 & $x$ & $X^{*}$ & & $x$ \\
\hline 4 & červencová & 2.-3. 7. 2018 & & $X^{*}$ & & $x$ \\
\hline 5 & srpnová & 2.-3. 8. 2018 & & $x$ & & $x$ \\
\hline 6 & zářijová & 3.-4. 9. 2018 & $x$ & $x$ & $x$ & $x$ \\
\hline 7 & říjnová & 2.-3. 10. 2018 & $x$ & $x$ & & $x$ \\
\hline 8 & listopadová & 1.-2. 11. 2018 & $x$ & $x$ & & $x$ \\
\hline
\end{tabular}


Tabulka 3. Meze stanovitelnosti nepolárních organických látek v ng na membránu Table 3. Limit of quantification of non-polar organic compounds in ng per membrane

\begin{tabular}{|c|c|c|c|}
\hline Název látky & $\begin{array}{l}\text { MS } \\
{\left[\mathrm{ng} \cdot \mathrm{me}^{-1}\right]}\end{array}$ & Název látky & $\begin{array}{l}\text { MS } \\
{\left[\mathrm{ng} \cdot \mathrm{me}^{-1}\right]}\end{array}$ \\
\hline $\mathrm{a}-\mathrm{HCH}$ & 2 & Benzo(b)fluoranthen & 5 \\
\hline$\beta-\mathrm{HCH}$ & 2 & Benzo(k)fluoranthen & 5 \\
\hline $\mathrm{Y}-\mathrm{HCH}$ & 2 & Benzo(a)pyren & 5 \\
\hline$\delta-\mathrm{HCH}$ & 2 & Indeno(123cd)pyren & 10 \\
\hline $\mathrm{HCB}$ & 2 & Dibenzo(ah)anthracen & 5 \\
\hline Heptachlor & 5 & Benzo(ghi)perylen & 5 \\
\hline $\begin{array}{l}\text { Heptachlorepoxid } \\
\text { trans }\end{array}$ & 2 & PBDE 28 & 0,05 \\
\hline $\begin{array}{l}\text { Heptachlorepoxid } \\
\text { cis }\end{array}$ & 5 & PBDE 47 & 0,05 \\
\hline Aldrin & 2 & PBDE 100 & 0,05 \\
\hline Isodrin & 5 & PBDE 99 & 0,05 \\
\hline Oxychlordan & 5 & PBDE 154 & 0,05 \\
\hline Dieldrin & 5 & PBDE 153 & 0,05 \\
\hline Endrin & 5 & PBDE 183 & 0,05 \\
\hline a-endosulfan & 5 & PCB 81 & 0,1 \\
\hline$\beta$-endosulfan & 5 & PCB 77 & 0,1 \\
\hline Trans-chlordan & 5 & PCB 126 & 0,1 \\
\hline Cis-chlordan & 5 & PCB 169 & 0,1 \\
\hline Metoxychlor & 5 & PCB 123 & 0,1 \\
\hline Mirex & 5 & PCB 114 & 0,1 \\
\hline o,p'-DDE & 2 & PCB 105 & 0,1 \\
\hline$p, p^{\prime}-D D E$ & 2 & PCB 167 & 0,1 \\
\hline o,p'-DDD & 2 & PCB 156 & 0,1 \\
\hline$p, p^{\prime}-D D D$ & 5 & PCB 157 & 0,1 \\
\hline o,p'-DDT & 2 & PCB 189 & 0,1 \\
\hline$p, p^{\prime}-D D T$ & 5 & PCB 28 & 0,1 \\
\hline Fenanthren & 10 & PCB 52 & 0,1 \\
\hline Anthracen & 5 & PCB 101 & 0,1 \\
\hline Fluoranthen & 5 & PCB 118 & 0,1 \\
\hline Pyren & 5 & PCB 153 & 0,1 \\
\hline Chrysen & 5 & PCB 138 & 0,1 \\
\hline Benzo(a)anthracen & 5 & PCB 180 & 0,1 \\
\hline
\end{tabular}

Tabulka 4. Meze stanovitelnosti polárních organických látek v ng na membránu Table 4. Limit of quantification of polar organic compounds in ng per membrane

\begin{tabular}{|c|c|c|c|}
\hline Název látky & $\begin{array}{l}\text { MS } \\
{\left[\text { ng.me }{ }^{-1}\right]}\end{array}$ & Název látky & $\begin{array}{l}\text { MS } \\
\left.\text { [ng.me }{ }^{-1}\right]\end{array}$ \\
\hline Acetochlor & 1 & Glyfosát & 1 \\
\hline Acetochlor ESA & 5 & Chloridazon desphenyl & 1 \\
\hline Acetochlor OA & 5 & $\begin{array}{l}\text { Chloridazon methyl } \\
\text { desphenyl }\end{array}$ & 1 \\
\hline Alachlor ESA & 5 & Isoxaflutole & 10 \\
\hline AMPA & 2 & Isoxafluton & 10 \\
\hline Atrazin & 5 & Linuron & 1 \\
\hline Atrazin-desethyl & 1 & Mesotrione & 10 \\
\hline Atrazine-2-hydroxy & 1 & Metazachlor & 1 \\
\hline Bentazon & 1 & Metazachlor ESA & 5 \\
\hline Benzotriazol & 10 & Metazachlor OA & 5 \\
\hline $\begin{array}{l}\text { Benzotriazol } \\
\text { methyl }\end{array}$ & 10 & Metolachlor & 5 \\
\hline Clomazone & 10 & Metolachlor ESA & 5 \\
\hline Cyprosulfamid & 10 & Metolachlor OA & 5 \\
\hline DEET & 10 & Metribuzin & 1 \\
\hline Dimetachlor & 1 & Terbuthylazin-DE-2-H & 5 \\
\hline Dimethachlor ESA & 10 & Terbutylazin & 1 \\
\hline Dimethachlor OA & 10 & Terbutylazin-2-hydro & 5 \\
\hline Dimethenomorph & 10 & Terbutylazin-desetyl & 5 \\
\hline Fluroxypyr & 10 & Thiencarbazone-methyl & 10 \\
\hline
\end{tabular}

Pro extrakci polárních látek z membrán typu POCIS bylo potřeba vzorkovač demontovat a sorbent mezi PES membránami kvantitativně převést do prázdné kolonky S PE fritou. Náplň POCIS-Glyphosate byla po převedení na kolonku sušena pod vakuem a poté eluována 0,1 M HCl [9]. Extrakt byl opatrně zahuštěn pod dusíkem a doplněn methanolem. Pro extrakci pesticidů z membrán POCISPharm byl použit methanol, u POCIS-Pes extrakce proběhla směsí rozpouštědel methanol, toluen a dichlormethan v poměru 1:1: 8 [10]. Pro kontrolu výtěžnosti byl do všech vzorků přidáván interní standard a v každé kampani byl se vzorky extrahován i slepý vzorek (blank). Po zakoncentrování a v prípadě POSIS-Pes převedení do methanolu byly vzorky analyzovány pomocí HPLC/MS/MS. Meze stanovitelnosti použitých analytických metod pro jednotlivé polární organické látky v nanogramech na membránu jsou uvedeny v tabulce 4. 


\section{VÝSLEDKY A DISKUSE}

\section{Hydrologická a klimatologická data}

Největší průtoky byly dosahovány $\vee$ jarních měsících, především $\vee$ březnu a dubnu vlivem odtávání sněhové pokrývky v první polovině března. Měsíc duben postrádal $v$ roce 2018 typický aprílový charakter počasí a byl teplotně výrazně nadnormální (cca $\mathrm{o}+5^{\circ} \mathrm{C}$ ). První srážkově bohatší období se vyskytlo 15. až 17. 5. s maximem 17. 5., kdy v povodí Martinického potoka napršelo 23 mm srážek. Tato srážka neměla prívalový charakter, projevila se však na všech měrných stanicích průtoku v této oblasti. O měsíc později 12. až 13. 6. proběhla obdobná srážka s maximálním denním úhrnem $23 \mathrm{~mm}$ dne 12. 6. v povodí Blažejovického potoka. Na rozdíl od předchozí srážkové události tato již měla prívalový charakter vlivem bouřkové činnosti. Letní období (4. a 5. vzorkovací kampaň) bylo typické prohlubujícím se srážkovým deficitem doprovázeným klimatickým a hydrologickým suchem s občasnými lokálními srážkami prívalového charakteru vlivem bouřkové činnosti. Chod srážek a průtoků v povodí Martinického potoka demonstruje obr. 5.

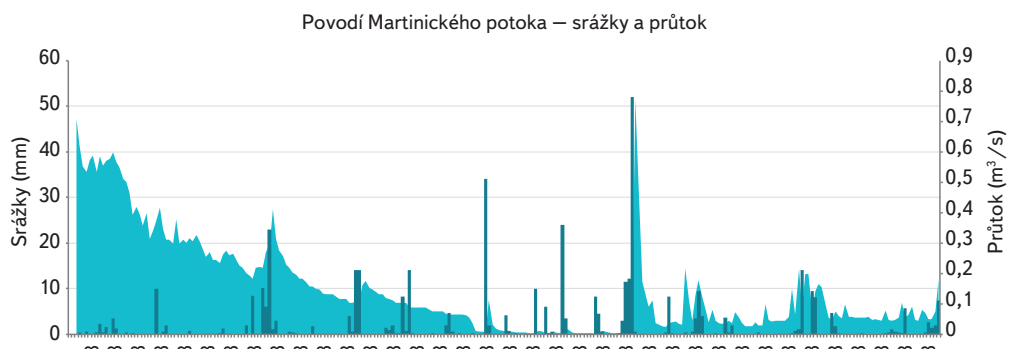

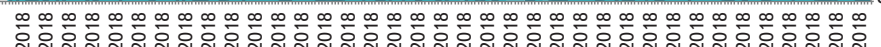

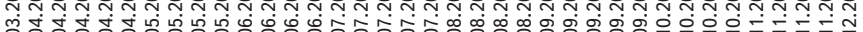

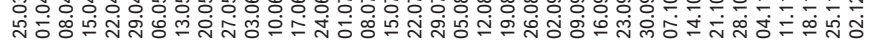

\section{Prưtok Srážky}

Obr. 5. Denní úhrn srážek ze stanice AMS1 Košetice a průměrný denní průtok ze stanice Senožaty na Martinickém potoce $v$ roce 2018

Fig. 5. Total daily precipitation on AMS1 Košetice station and average daily flow on Senožaty station in Martinický stream, 2018 year

Největší úhrny srážek byly zaznamenány na přelomu srpna a září 31. 8. až 3. 9.2018 během 5. vzorkovací kampaně, kdy širší oblast v dolní části povodí Želivky zasáhla rozsáhlá kupovitá oblačnost doprovázená bouřkami s krátkými, ale velmi intenzivními srážkami. Vzhledem ke vzniku několika navazujících srážkových událostí během těchto tří až čtyř dní došlo po nasycení půdního profilu vodou k masivní erozi zemědělské pưdy právě v období po sklizni většiny plodin (mimo kukuřici), kdy byla pole bez vegetačního pokryvu. Následkem toho došlo k silné erozi, v povodí Zahrádčického potoka až enormní a k přemodelování koryta potoka (obr. 6).

Největší denní úhrny srážek byly zaznamenány na stanici AMS1 Košetice 3. 9., a to $52 \mathrm{~mm}$. V podzimních měsících se v povodí Blažejovického potoka vydatnější srážka (nad 10 mm) vyskytla ještě 19. 9., 23. 9. a 24. 10. 2018. V říjnu nejvydatněji pršelo v povodí Martinického potoka 24., 27. a 28. 10. 2018. Listopad byl na srážky velice chudý (obr. 7).

\section{Nepolární organické látky}

Přestože aplikace organochlorových pesticidů (OCP) je již téměř 50 let zakázána, jejich prítomnost byla v povrchové vodě potvrzena. Z hexachlorcyklohexanu $(\mathrm{HCH})$ se nejčastěji vyskytly izomery Lindan $(\mathrm{\gamma}-\mathrm{HCH})$ a $\delta-\mathrm{HCH} \vee$ koncentracích do max. 45 ng/SPMD v profilu Želivka-Miletín (lokalita č. 8, obr. 8).
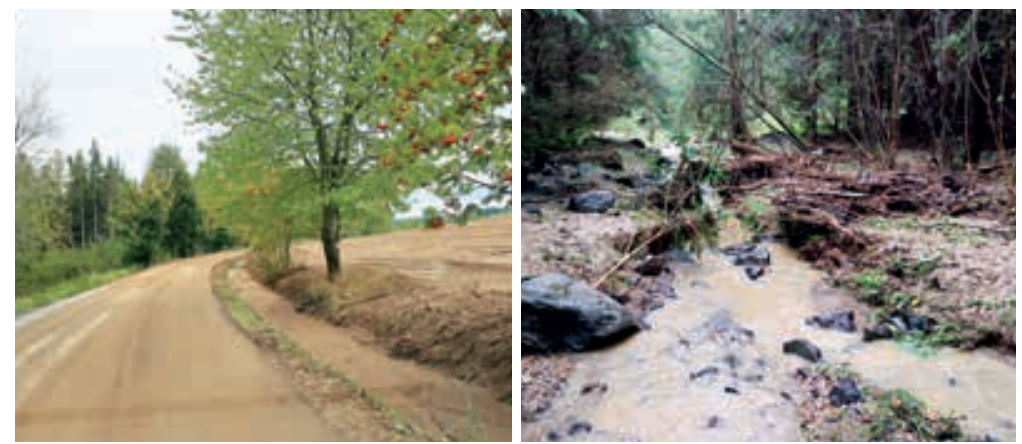

Obr. 6. Půdní eroze v povodí Zahrádčického potoka a dopad srážky 2. 9. 2018 na tok (foto 3. 9. 2018)

Fig. 6. Soil Erosion in Zahrádčický stream basin and precipitation event impact $2^{\text {nd }}$ September 2018 on the stream (photo $3^{\text {rd }}$ September 2018)

Srážkové úhrny

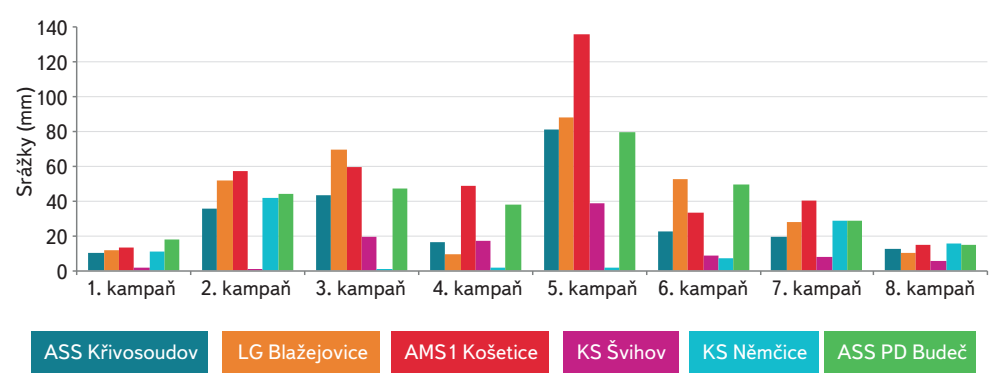

Obr. 7. Celkový úhrn srážek během jednotlivých vzorovacích kampaní v roce 2018 Fig. 7. Total precipitation during each sampling campaign in 2018 year

Izomery $\mathrm{HCH}$ - červnová kampaň
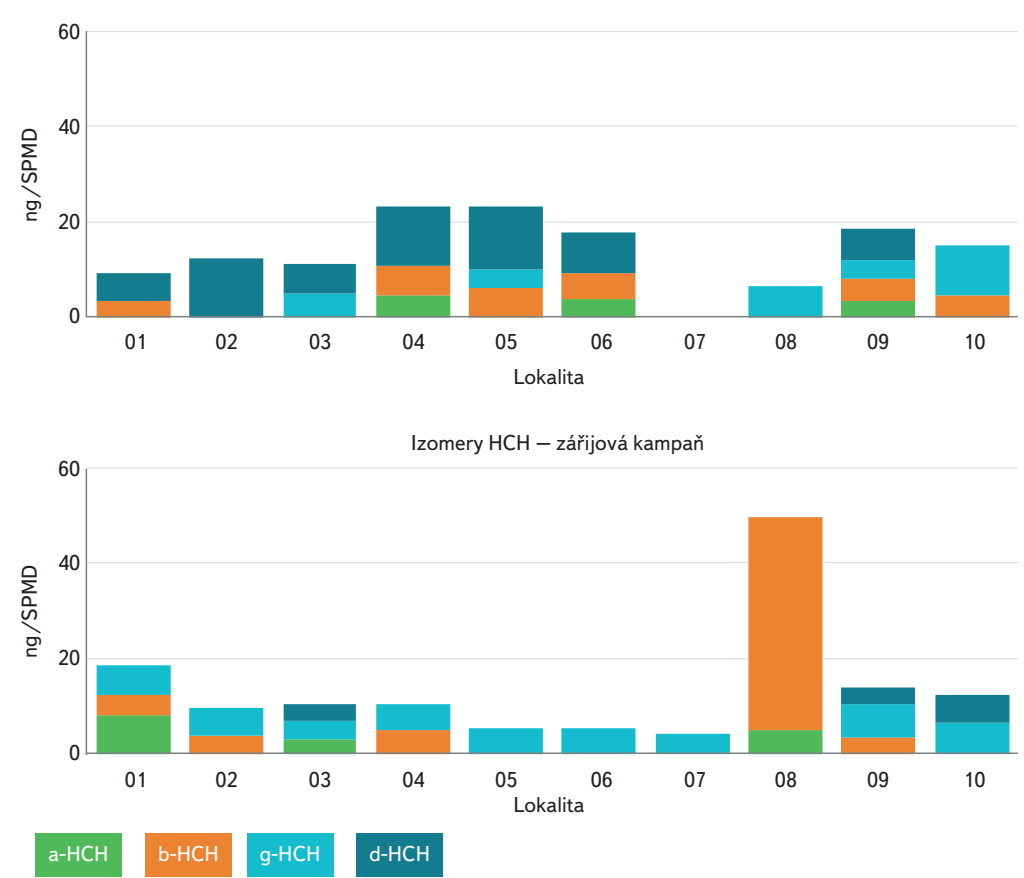

Obr. 8. Obsah izomerů HCH v prítocích VN Švihov - SPMD (expozice 30 dní) Fig. 8. HCH isomer concentrations in WR Švihov tributaries - SPMD (exposure 30 days) 
Na všech lokalitách téměř ve všech pěti kampaních byl v SPMD detekován hexachlorbenzen (HCB). Nejvyšší koncentrace byly nalezeny v Medulánu (červen), Šetějovickém potoce (duben) a Zahrádčiském potoce (září; 52 ng/SPMD). Velmi četný výskyt byl potvrzen jak mateřských sloučenin DDT (p,p'-DDT, $\left.o, p^{\prime}-D D T, p, p^{\prime}-D D D, o, p^{\prime}-D D D\right)$, tak i dehydrochlorovaných $p, p^{\prime}-D D E$ a o, $p^{\prime}-D D E$. Vazba koncentrace $p, p^{\prime}$-DDT na chod srážek, resp. na půdní erozi a průtok v recipientu se nejvýrazněji projevila ve všech lokalitách v záriijové kampani, zvláště pak $\vee$ Tomickém, Zahrádčickém, Martinickém a Lohenickém potoce (lokality č. 3, 4,7 a 9, obr. 9). V některých lokalitách převažovalo zastoupení izomerů DDT nad DDE (Tomický, Zahrádčický a Martinický potok), v Medulánu, VN Němčice a v Želivce-Miletíně převažovaly izomery DDE. V surové vodě z VN Švihov bylo zastoupení DDT a DDE vyrovnané a po Sedlickém potoce (VN Němčice) druhé nejnižší (obr. 10).

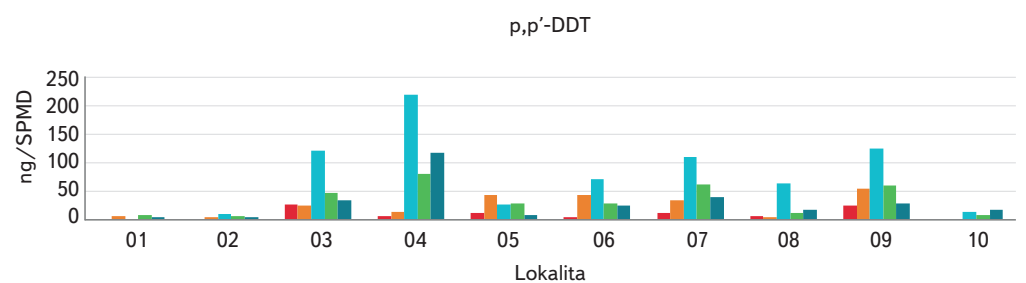

\section{duben červen záři řjijen listopad}

Obr. 9. Obsah p,p'-DDT v prítocích VN Švihov - SPMD (expozice 30 dní)

Fig. 9. Content of p, $p^{\prime}$-DDT concentrations in WR Švihov tributaries - SPMD (exposure 30 days)

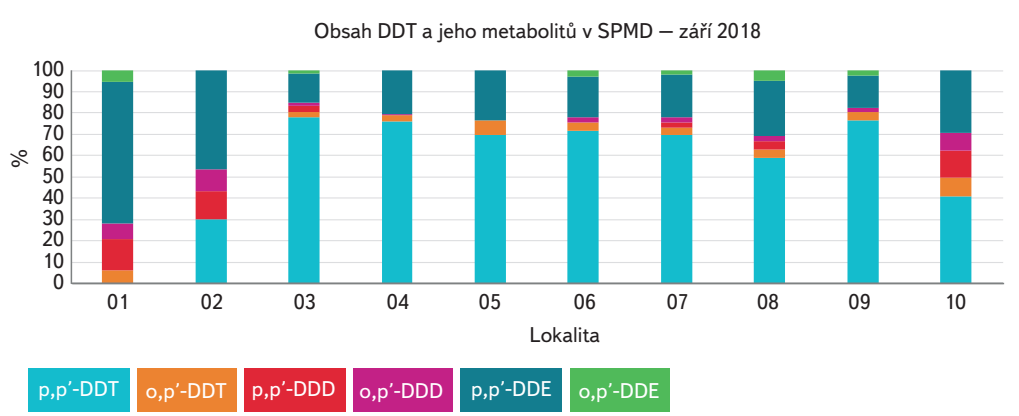

Obr. 10. Procentuální zastoupení DDT a jeho metabolitů v př́itocích VN Švihov - SPMD Fig. 10. Percentage of DDT and its metabolites in WR Švihov tributaries - SPMD

Z drinů se na prítocích do VN Švihov pravidelně objevoval pouze aldrin s maximem 41 ng/SPMD ve VN Němčice (lokalita č. 2) v červnové kampani, isodrin jen zř́dka, endrin pouze v červnové kampani v Tomickém potoce (lokalita č. 3) a dieldrin nebyl potvrzen vůbec. Jen sporadicky bylo možno v membránách SPMD nalézt chlorované deriváty benzenu (tetra-, penta-), oktachlorstyrenu a heptachlorepoxidu-A v jednotkách ng na SPMD.

Polybromované diphenylethery byly analyzovány pouze v SR membránách ve velmi nízkých koncentracích do 0,41 ng/vzorek (MS =0,05 ng/vz). Detekovány byly kongenery PBDE 47 a PBDE 99. Ostatní kongenery PBDE 28, 100, 153, 154 a 183 nebyly potvrzeny.

S vysokou citlivostí SR membrány detekovaly polychlorované bifenyly (PCB). Analyzovány byly kongenery PCB $\mathbf{2 8}, \mathbf{5 2}, 77,81, \mathbf{1 0 1}$, 105, 114, 118, 123, 126, 138, 153, 156, 157, 167, 169, 180 a 189. Četné byly nálezy kongenerů specifikovaných nařízením vlády č. 401/2015 Sb. (v předchozí větě zvýrazněny), a to jak z hlediska lokalit, tak i jednotlivých vzorkovacích kampaní. Nejvíce zastoupeným byl kongener PCB 153 (obr. 11). Z míry zastoupení jednotlivých kongenerů PCB se dá usuzovat na prevažující historickou kontaminaci Delorem 106, v jehož složení převažovaly hexachlorbifenyly (zde zastoupené PCB 138 a PCB 153). Tento prípravek se použival v letech 1961 až 1984 jako elektroizolační kapalina a do nátěrových hmot (např. [11]). Nejvyšší obsahy kongeneru 153 byly potvrzeny v Lohenickém potoce (lokalita č. 9) a ve VN Němčice v povodí Sedlického potoka (lokalita č. 2, obr. 12).

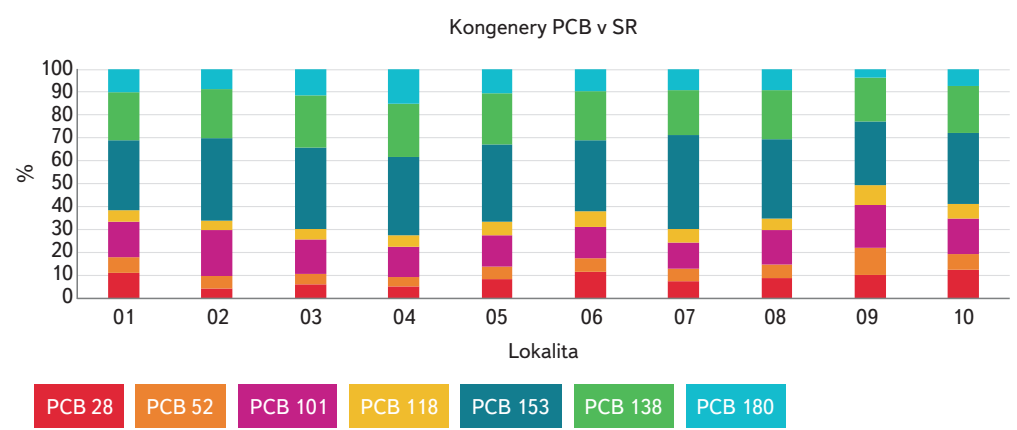

Obr. 11. Procentuální zastoupení kongenerů PCB v př́tocích VN Švihov Fig. 11. Percentage of PCB congeners in WR Švihov tributaries - SR

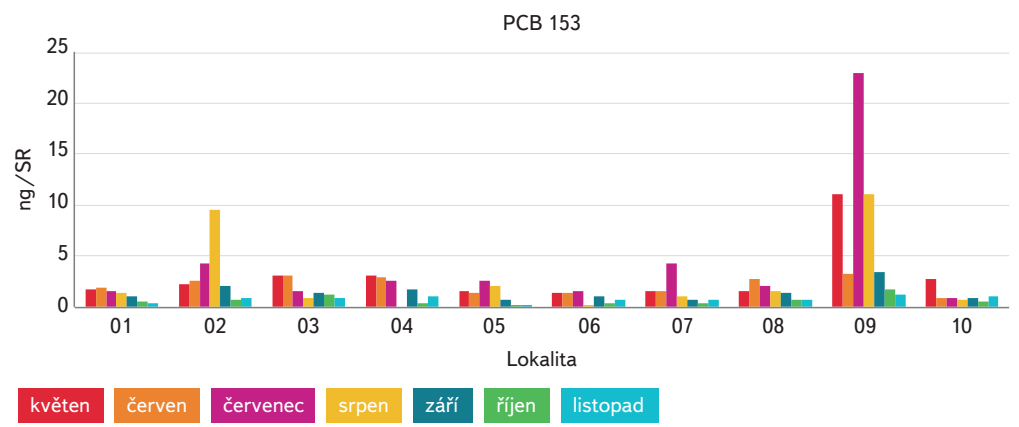

Obr. 12. Obsah kongeneru PCB 153 v prítocích VN Švihov - SR (expozice 30 dní) Fig. 12. PCB 153 concentrations in WR Švihov tributaries - SR (exposure 30 days)

Podíváme-li se podrobněji na nálezy PCB v Lohenickém potoce, je zajímavé, že na rozdíl od předchozích prezentovaných polutantů nebyla jejich dynamika výskytu v rámci vegetační sezony závislá na chodu srážek a půdní erozi (obr. 13). Nejnižší obsah PCB byl shledán v Blažejovickém potoce (lokalita č. 6) a v surové vodě vstupující do ÚV Želivka (lokalita č. 10).

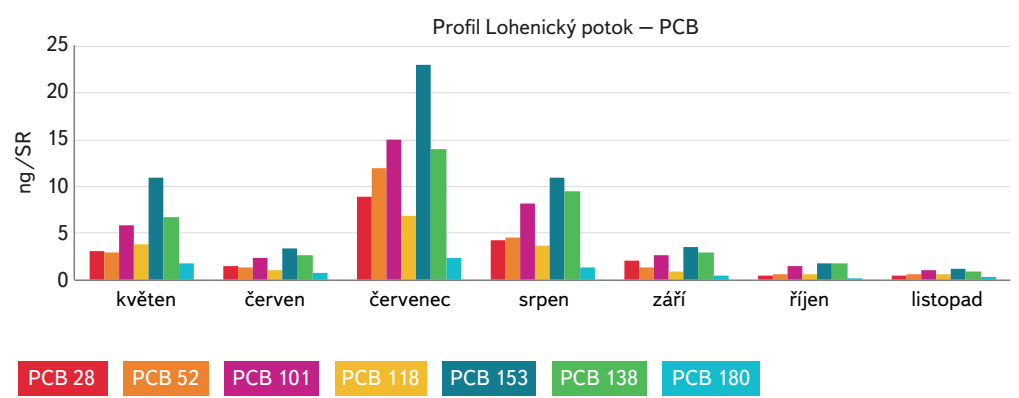

Obr. 13. Obsah kongenerů PCB v Lohenickém potoce - SR (expozice 30 dní) Fig. 13. PCB Congeners concentration in Lohenický stream - SR (exposure 30 days)

Polycyklické aromatické uhlovodíky byly v membránách SR a SPMD na nejvyšších koncentračních úrovních ze všech sledovaných nepolárních organických látek. Fenanthren, fluoranthen a pyren tvořily 79 až 87 \% z 12 analyzovaných PAU (obr. 14). Jejich koncentrace dosahovaly stovek nanogramů na membránu, vyšší byla v první polovině roku, zvláště v dubnu (po zimním období) a na většině lokalit postupně klesala až do řijnové vzorkovací kampaně. $V$ listopadu s nástupem zimy koncentrace PAU v membránách opět vzrostla (obr. 15). 
Tento charakter chodu koncentrací odráží především atmosférický původ znečištění PAU a není až tak závislý na průtocích. Koncentrace benzo(a)pyrenu byla cca 10 až 12× nižší než dominantního fluoranthenu. Nejnižší nálezy byly shledány ve VN Němčice (lokalita č. 2) a VN Švihov (surová voda, lokalita č. 10), což je dáno vazbou PAU na nerozpuštěné látky a jejich sedimentací v nádrži.

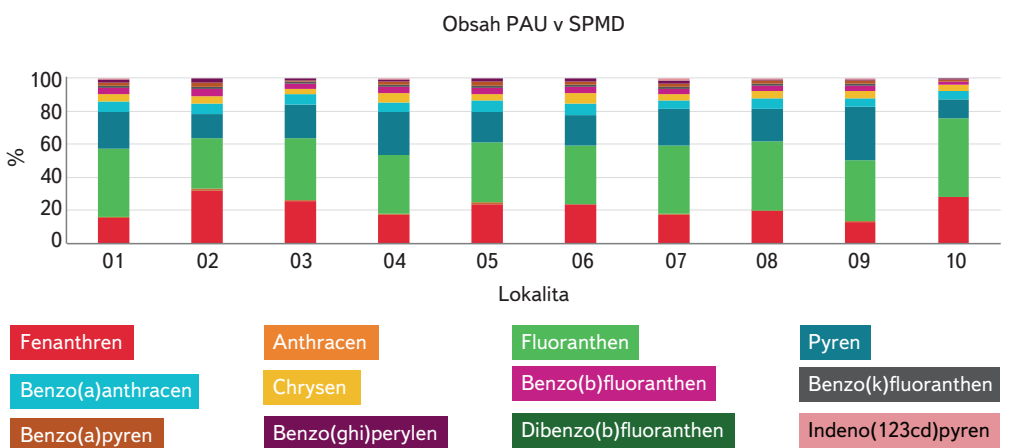

Obr. 14. Procentuální zastoupení PAU v prítocích VN Švihov - SPMD Fig. 14. Percentage of PAHs in WR Švihov tributaries - SPMD

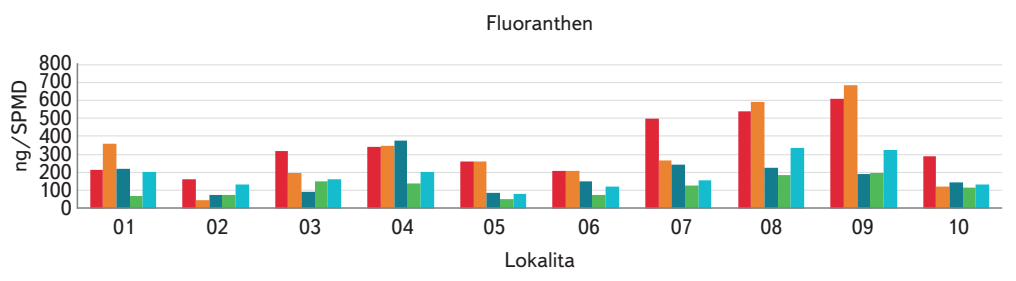

duben červen zárí řijen listopad

Obr. 15. Obsah fluoranthenu v prítocích VN Švihov - SPMD (expozice 30 dní) Fig. 15. Fluoranthene concentration in WR Švihov tributaries - SPMD (exposure 30 days)

\section{Polární organické látky}

Pasivním monitoringem bylo ověřováno celkem 38 polárních látek, převážně účinných látek rostlinolékařských prípravků. Většina pozitivních nálezů s vyšší koncentrací byla potvrzena v membránách z květnové expozice. V mnoha případech koncentrace metabolitů přesahovala obsah mateřských sloučenin. To platí zvláště pro atrazin, dimethachlor a terbuthylazin. Jejich výskyt byl potvrzen téměř ve všech ověřovaných lokalitách. Přitom atrazin je zakázáno používat od 1. 8. 2005. Je překvapující, že nejvyšší obsah atrazinu a jeho metabolitů byl zjištěn v surové vodě z VN Švihov (lokalita č. 10). Dimethachlor, herbicid, používaný na olejniny, nebyl nalezen v povodích př́toků, kde nebyla nasazena řepka (Brassica napus) nebo se jí oseté plochy nacházely dál od vodních toků (obr. 16).

Naopak v případě metazachloru, jenž je rovněž aplikován na olejniny, byla detekována pouze mateřská látka, jeho metabolity nebyly nalezeny, jak dokumentuje obr. 17. Velmi vysoký obsah metazachloru v Zahrádčickém potoce (lokalita č. 4) ze záriijové kampaně souvisí s přívalovou srážkou 2. a 3. 9., kdy došlo k enormní erozi půdy ze zemědělských ploch a splachu do povrchových vod.

Terbuthylazin a jeho metabolity náležely na prítocích do VN Švihov k nejhojněji zastoupeným pesticidům ve vysoké koncentraci. Souvisí to s vysokým podílem osevných ploch zastoupených kukuřicí. V jarní vzorkovací kampani byl detekován mateřský terbutylazin spolu s metabolity, v podzimní zárijové kampani byl nalezen výhradně metabolit terbuthylazin-2-hydro. Překvapující byl opět vysoký obsah terbuthylazinu a jeho metabolitů z jarní kampaně v surové vodě (lokalita č. 10, obr. 18). Maximální obsahy v Zahrádčickém potoce (lokalita č. 4) a Martinickém potoce (lokalita č. 7) z podzimní kampaně souvisí se srážkovou epizodou 1. až 3. 9. a případně 23. 9. 2018.
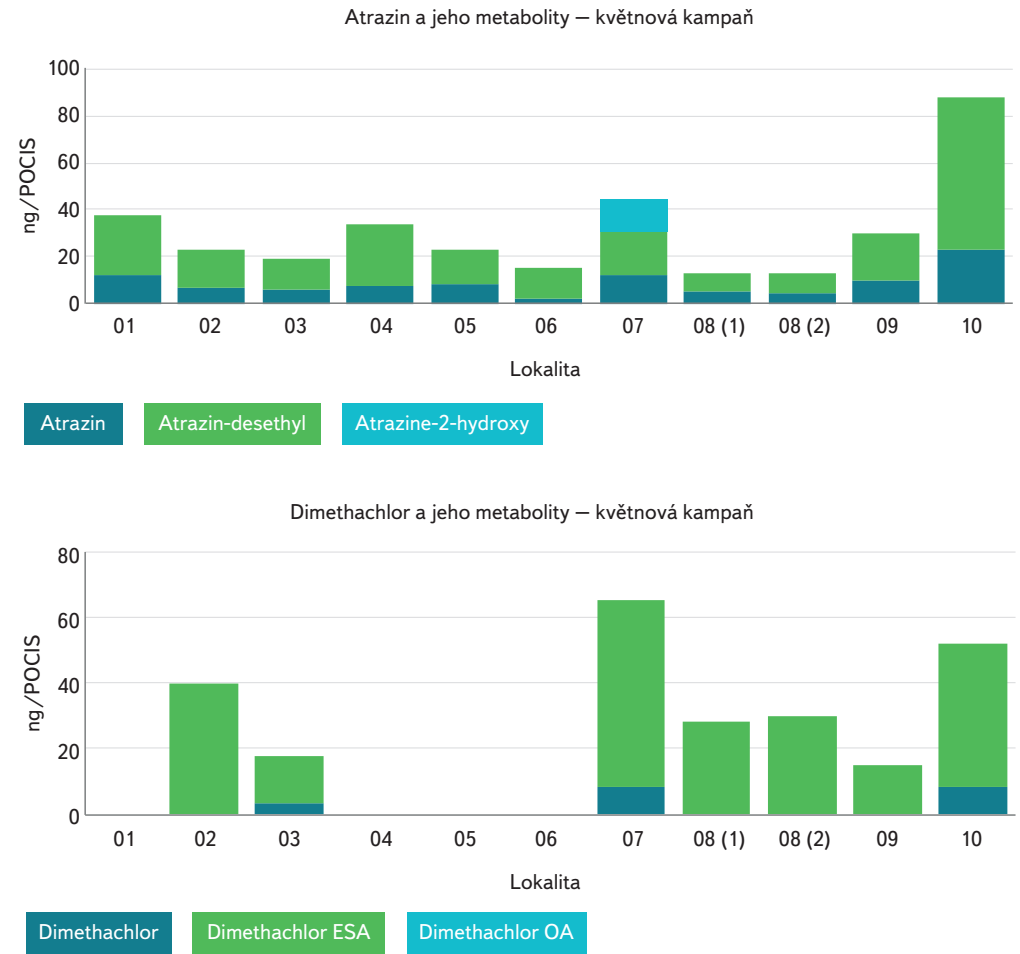

Obr. 16. Obsah atrazinu, dimethachloru a jejich metabolitů v prítocích VN Švihov POCIS (expozice 30 dní)

Fig. 16. Atrazine, dimethachlor and its metabolites concentration in WR Švihov tributaries - POCIS (exposure 30 days)
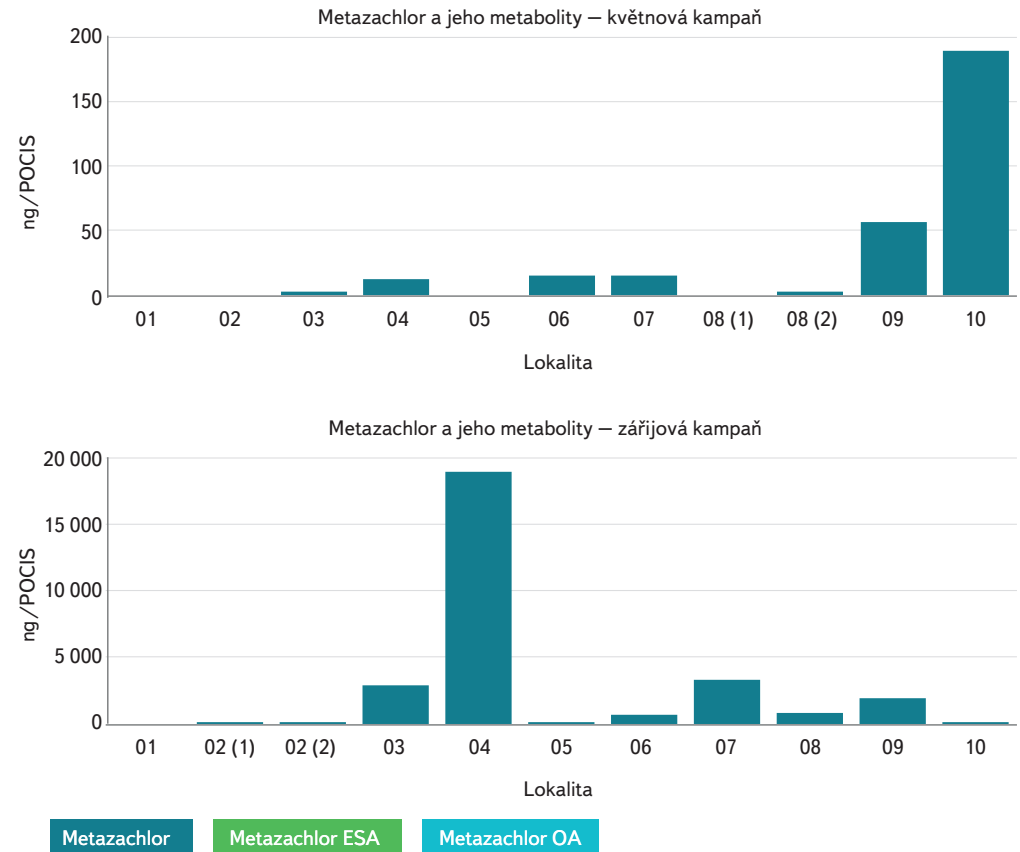

Obr. 17. Obsah metazachloru a jeho metabolitů v prítocích VN Švihov - POCIS (expozice 30 dní)

Fig. 17. Metazachlor and its metabolites concentration in WR Švihov tributaries - POCIS (exposure 30 days)

Jedním z nejvíce znečištěných prítoků VN Švihov pesticidy se jeví Medulán (lokalita č. 1), ač náleží k těm nejkratším. Byly v něm v jarní květnové vzorkovací kampani potvrzeny vysoké obsahy terbuthylazinu, metolachloru, cyprosulfamidu 

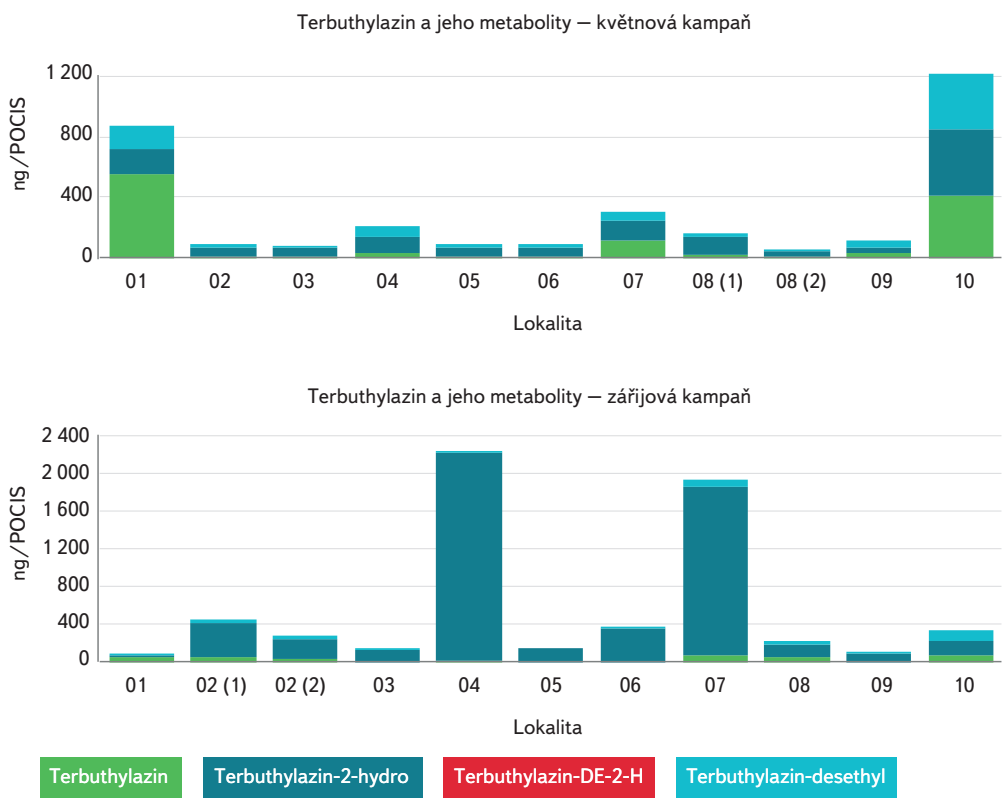

Obr. 18. Obsah terbuthylazinu a jeho metabolitů v prítocích VN Švihov - POCIS (expozice 30 dní)

Fig. 18. Terbuthylazin and its metabolites concentration in WR Švihov tributaries - POCIS (exposure 30 days)
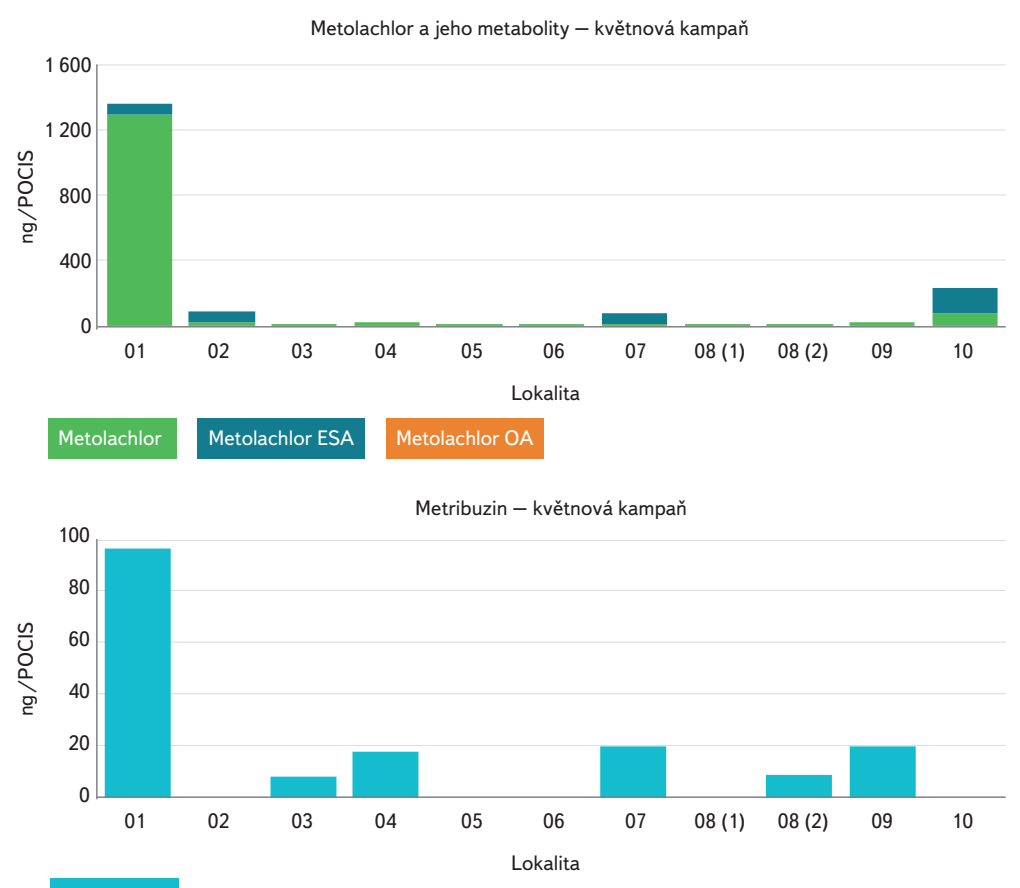

\section{Metribuzin}

Obr. 19. Obsah metolachloru a metribuzinu v prítocích VN Švihov - POCIS

(expozice 30 dní)

Fig. 19. Metolachlor and metribuzin concentration in WR Švihov tributaries - POCIS (exposure 30 days)

a thiecarbazone-methylu (aplikace na kukuřici) a metribuzinu (aplikace na brambory) (obr. 19). V jeho povodí se pěstovala převážně kukuřice, a to téměř až na hranici OPVZ I, cca 50 m od vodoteče (obr. 20).

Ostatní pesticidy byly nacházeny v nižších koncentracích a jen na některých lokalitách. Nad 100 ng/POCIS byly potvrzeny: klomazon (používaný v menším

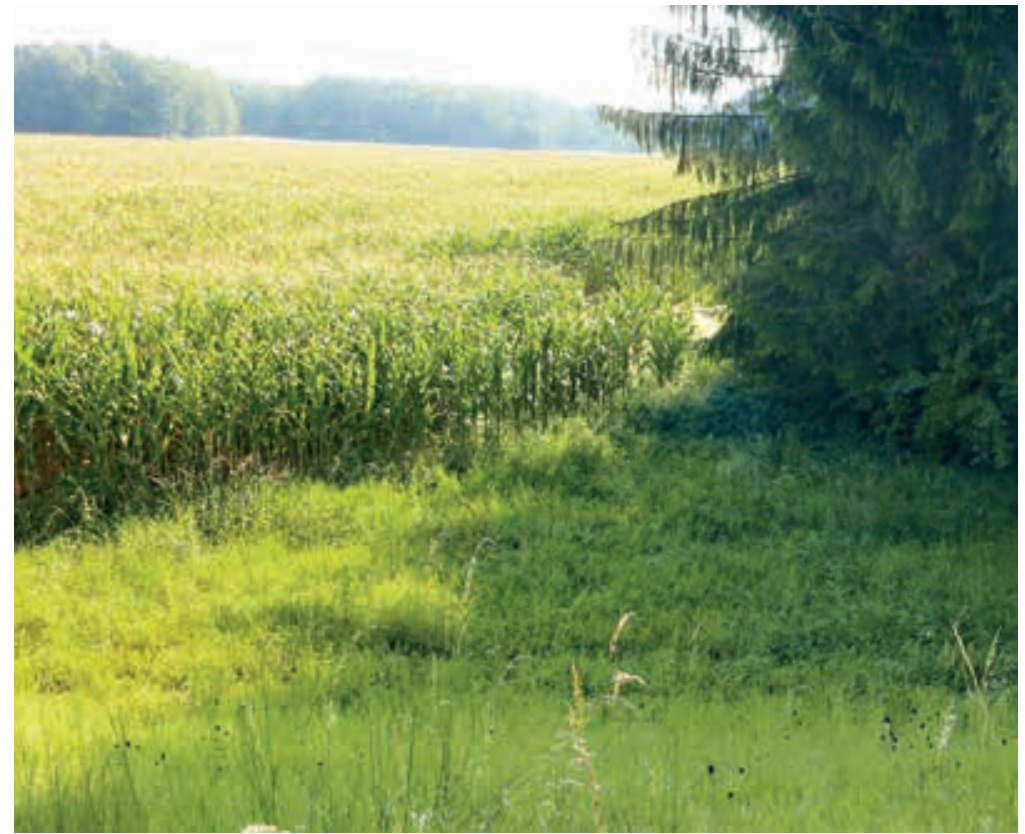

Obr. 20. Kukuřičné pole v povodí Medulánu

Fig. 20. The maize field in Medulán basin

množství na olejniny), metabolity chloridazonu (na ošetření cukrové repy) a thiecarbazone-methyl (na ošetření kukuřice). Četný byl výskyt benzotriazolu (inhibitor koroze) a diethyltoluamid - DEET (účinná látka repelentů proti bodavému hmyzu). Ukázka pozitivních nálezů pesticidů a obou výše zmíněných látek v surové vodě vstupující do úv Želivka, a. s., (lokalita č. 10) je na obr. 21. Jarní měsíce náleží zpravidla k pesticidy nejexponovanějšímu období v povrchových vodách a nejinak tomu bylo i v prípadě obsahu těchto látek v surové vodě. $\vee$ záríijové kampani bylo spektrum nalezených pesticidů výrazně nižší a nižší byly i koncentrace dominantních pesticidů metazachloru a terbuthylazinu včetně jeho metabolitů (obr. 22). Tento „průběh“ koncentrací účinných látek rostlinolékařských přípravků během vegetačního období potvrzuje i obr. 23 $\checkmark$ př́padě metabolitu AMPA. Samozřejmě vždy záleží na konkrétních podmínkách, které v daném roce nastanou.

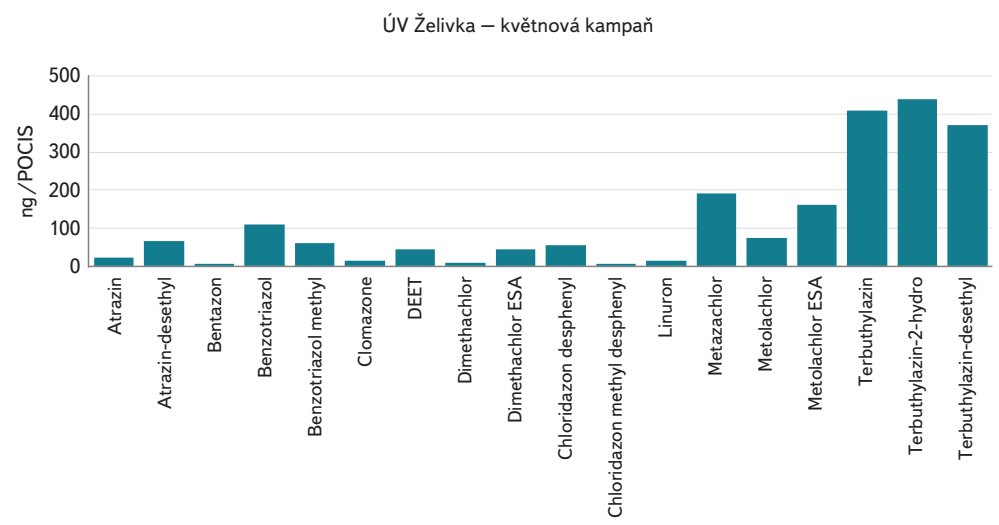

Obr. 21. Obsah pesticidů a jejich metabolitů v surové vodě - POCIS (květnová kampaň) (expozice 30 dní)

Fig. 21. Pesticides and its metabolites concentration in raw water - POCIS (May campaign) (exposure 30 days)

Obsah zachycených látek membránami pasivních vzorkovačů je možno přepočitat na průměrnou koncentraci během expozice, tzv. TWA koncentraci (Time Weighted Average concentration), pokud je pro danou látku známá 


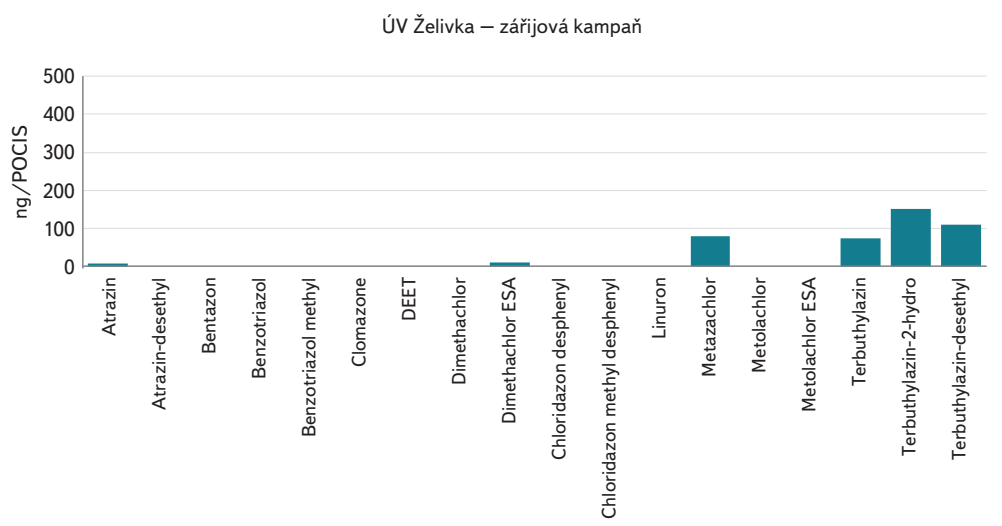

Obr. 22. Obsah pesticidů a jejich metabolitů v surové vodě - POCIS (záŕijová kampaň) (expozice 30 dní)

Fig. 22. Pesticides and its metabolites concentration in raw water - POCIS (September campaign) (exposure 30 days)

vzorkovací rychlost $R_{\mathrm{s}}$ (Sampling Rate) v I.den ${ }^{-1}$ (vzorkovací rychlost pro daný vzorkovací systém a látku se různí). Pro přepočet platí následující vztah:

$$
C_{T W A}=N^{t} /\left(R_{s} \cdot t\right)
$$

kde: $N^{t}$ je množství zachycené látky vzorkovačem $v$ ng a $t$ je doba expozice vzorkovače ve dnech. Výsledná koncentrace $C_{T W A}$ je vyjádřena v ng..$^{-1}$.

Přepočtem podle rovnice (1) s využitím vzorkovací rychlosti $R_{\mathrm{s}}$ publikované Ahrensem [12] jsou koncentrace vybraných účinných látek rostlinolékařských prípravků v surové vodě $C_{T W A}$ uvedeny v tabulce 5 .

Vzorkovací rychlost v tabulce 5 u květnové a zárijijové kampaně se liší z důvodu použití dvou různých vzorkovačů POCIS: ke květnové kampani byl exponován POCIS-Pes a v zárijové kampani POCIS-Pharm.

Širokospektrální herbicid a desikant glyfosát je používán převážně na ošetření obilnin a olejnin. Klasický POCIS-Pharm nebo POCIS-Pes je na záchyt této silně polární látky málo účinný. V zárijové kampani byl poprvé použit POCIS-Gly pasivní vzorkovač, který byl speciálně vyvinutý pro záchyt silně polárních látek. Vzhledem k snadné degradaci glyfosátu byl v membránách POCIS-Gly detekován převážně jeho metabolit AMPA (kyselina aminomethylfosfonová). Nejnižší koncentrace obou látek byly potvrzeny v surové vodě (lokalita č. 10). Pasivní monitoring $\vee$ surové vodě pokračoval $\vee$ roce 2019 v celkem devíti měsícních kampaních, kdy se potvrdily sezonní zvýšené koncentrace metabolitu AMPA odpovídající dobám, kdy je glyfosát aplikován (obr. 23). Přepočtem na $C_{\text {TWA }}$ podle vztahu (1) se koncentrace metabolitu AMPA $\vee$ surové vodě pohybovala v rozmezí < 0,55-6,2 ng. $\mathrm{I}^{-1}\left(\mathrm{R}_{\mathrm{s}}=0,122 \mathrm{I} \cdot \mathrm{d}^{-1}[13]\right)$. Glyfosát nebyl v surové vodě detekován.

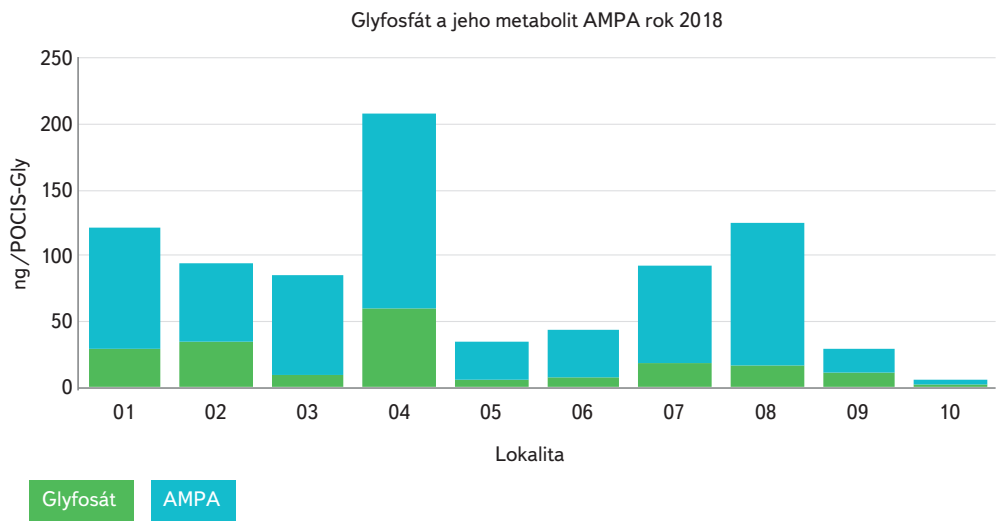

Obsah AMPA v surové vodě (lokalita č. 10) rok 2019

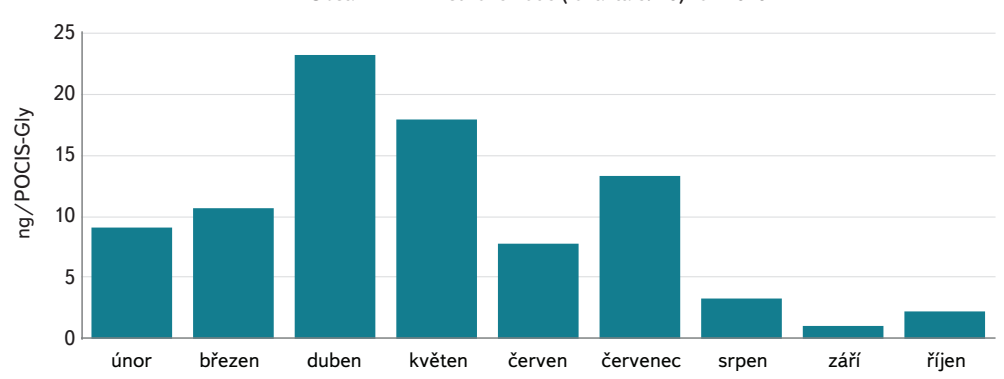

Obr. 23. Obsah glyfosátu a AMPA v prítocích do VN Švihov a v surové vodě - POCIS Gly (expozice 30 dní)

Fig. 23. Glyphosate and AMPA concentration in WR Švihov tributaries and in raw waterPOCIS Gly (exposure 30 days)

\section{ZÁVĚR}

Pasivním monitoringem významných prítoků do VN Švihov a surové vody vstupující do úpravny vody Želivka, a. s., po dobu jedné vegetační sezony od dubna do listopadu v roce 2018 byla sledována časoprostorová dynamika vnosu nepolárních a polárních organických látek do VN Švihov. Byly potvrzeny odlišné charakteristiky vnosu jednotlivých skupin mikropolutantů do vodárenské nádrže. Přestože organochlorové pesticidy HCH, PCB a DDT nejsou již několik desetiletí použivány, vzhledem k jejich perzistenci v prostředí přetrvávají a byly detekovány. Př́znivá je úroveň znečištění povrchové vody bromovanými difenylethery (retardéry hoření), která byla velice nízká. Z nepolárních organických látek je dominantní znečištění polycyklickými aromatickými uhlovodíky, které převažuje v první polovině roku a po letním poklesu koncentrací roste opět v pozdním podzimu.

Tabulka 5. Prưměrná koncentrace $C_{\text {TwA }}$ vybraných látek během expozice vzorkovače POCIS v surové vodè ÚV Želivka z květnové a zárijové kampaně 2018 Table 5. Time Weighted average concentration $C_{\text {TWA }}$ of selected compounds from POCIS sampling in raw water DWTP Želivka-May and September campaign 2008

Úv Želivka - surová voda

Květnová kampaň 2018

Zářijová kampaň 2018

\begin{tabular}{|c|c|c|c|c|c|c|}
\hline Název látky & $\mathbf{N}^{\mathrm{t}}$ [ng] & $\mathbf{R}_{\mathrm{s}}\left[\mathbf{I} \cdot \mathrm{d}^{-1}\right]$ & $C_{\text {TWA }}\left[\right.$ ng. $\left.\left.\right|^{-1}\right]$ & $\mathbf{N}^{\mathrm{t}}[\mathrm{ng}]$ & $R_{s}\left[I . d^{-1}\right]$ & $C_{\text {TWA }}\left[\right.$ ng. $\left.\mathrm{I}^{-1}\right]$ \\
\hline Terbuthylazin & 410 & 0,72 & 47,8 & 73 & 0,45 & 5,6 \\
\hline Terbuthylazin-desethyl & 370 & 1,62 & 7,1 & 110 & 0,97 & 3,9 \\
\hline Metazachlor & 190 & 0,81 & 7,3 & 79 & 0,5 & 5,5 \\
\hline Metolachlor & 75 & 0,24 & 9,8 & $<M S$ & 0,22 & - \\
\hline
\end{tabular}


Dynamika vnosu účinných látek rostlinolékařských prípravků je závislá na druhové skladbě zemědělských plodin, době aplikace přípravků a na srážko-odtokových poměrech. Byl potvrzen významný vliv chodu srážek a půdní eroze na množství vyplavovaných pesticidů do povrchových vod. $V$ roce 2018 to bylo potvrzeno predevším v povodí Zahrádčického, Martinického a Tomického potoka. Jedním z nejvíce znečištěných prítoků VN Švihov pesticidy se jeví potok Medulán. Nejvyšší koncentrace pesticidů v pasivních vzorkovačích (nad $1000 \mathrm{ng} / \mathrm{membránu}$ ) byly potvrzeny pro terbuthylazin a jeho metabolity terbuthylazin-2-hydro a terbuthylazin-desethyl, metolachlor a metazachlor. Je potřeba uvést, že tyto obsahy byly dosaženy během 30denní expozice membrán pasivních vzorkovačů.

\section{Poděkování}

Príspěvek byl zpracován v rámci projektu „Čistá voda - zdravé město: Cizorodé látky ve vodách podzemních, povrchových a odpadnich" (registrační čislo projektu CZ.071.02/0.0/ 0.0/16_040/0000378), Koncept I "Studie vnosu pesticidů do vodárenské nádrže Švihov (Želivka) s využitím nových vzorkovacích technik a odstranění organických látek ze sorpčních filtrů za ozonizací vysoce-účinnou chemickou destrukcí".

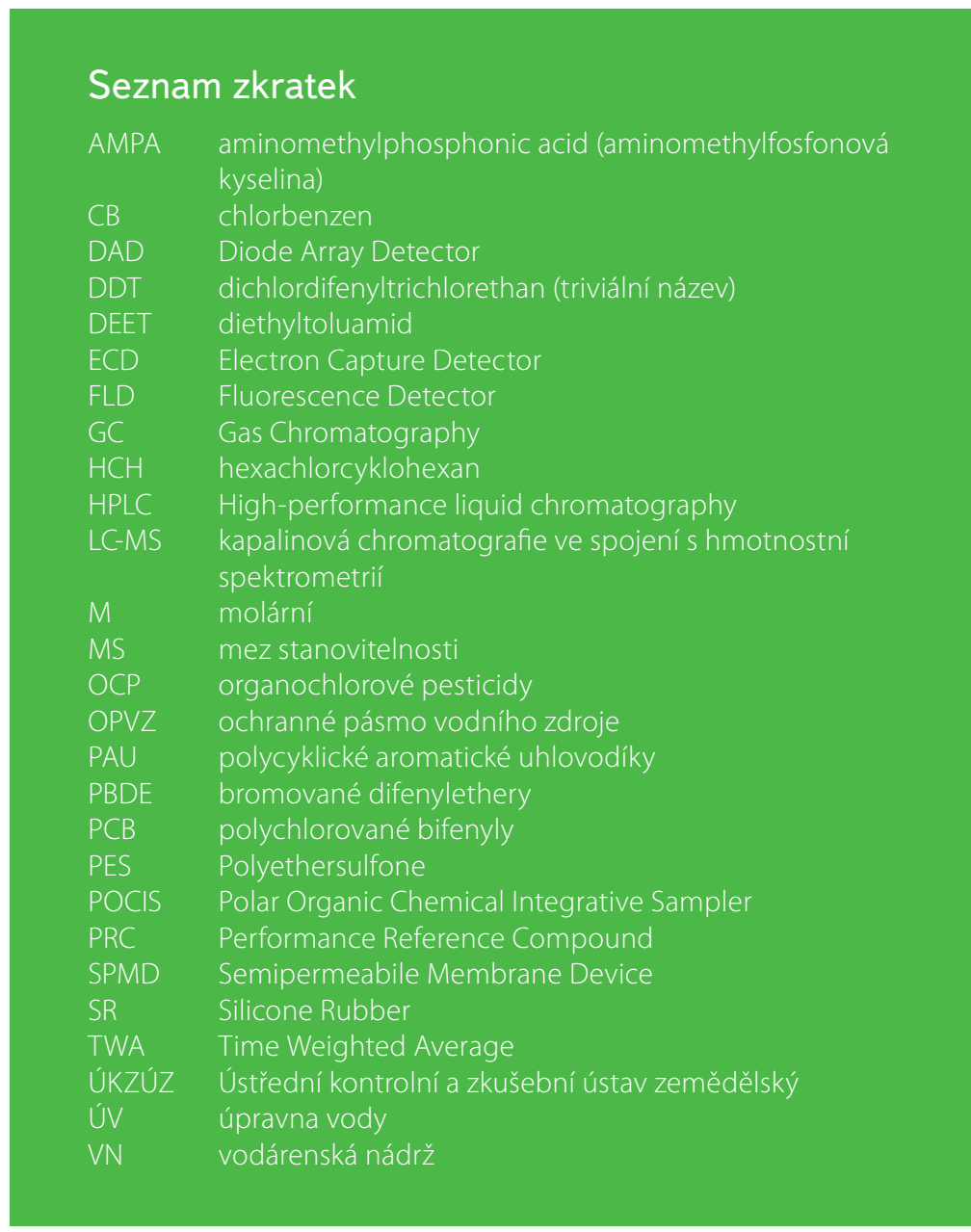

\section{Literatura}

[1] KVÍTEK, T. a kol. Retence a jakost vody v povodí vodárenské nádrže Švihov na Želivce. Praha: Povodí Vltavy, s. p., 2017, s. 21. ISBN 978-80-270-2488-9.

[2] LIŠKA, M., SOUKUPOVÁ, K., DOBIÁŠ, J., METELKOVÁ, A., GOLDBACH, J. a KVÍTEK, T. Jakost vody ve vodárenské nádrži Švihov na Želivce a jejím povodí se zaměřením na specifické organické látky. Vodohospodářské technicko-ekonomické informace, 2016, roč. 58, č. 3, s. 4-10. ISSN 0322-8916.
[3] DOBIÁŠ, J. KOŽELUH, M. ZAJÍČEK, A. FUČÍK, P. a LIŠKA, M. Dynamika vyplavování pesticidních látek $v$ povodí Čechtického potoka. Vodohospodářské technicko-ekonomické informace, 2018, roč. 60, č. 4, s. 10-16. ISSN 0322-8916.

[4] Spotřeba účinných látek obsažených $\vee$ prípravcích na ochranu rostlin v jednotlivých krajích a okresech (on-line). Dostupné z: http://eagri.cz/public/web/ukzuz/portal/pripravky-na-or/ucinnelatky-v-por-statistika-spotreba/spotreba-pripravku-na-or/spotreba-por-kraje-okresy/

[5] MYERS, J.P., ANTONIOU, M.N., BLUMBERG, B., et al. Concerns over use of glyphosate-based herbicides and risks associated with exposures: a consensus statement. Environmental Health, 2016 15, 19, p. 1-13.

[6] Prováděcí nařízení Komise (EU) 2017/2324 ze dne 12. prosince 2017, kterým se v souladu s nařízením Evropského parlamentu a Rady (ES) č. 1107/2009 o uvádění prípravků na ochranu rostlin na trh obnovuje schválení účinné látky glyfosát a mění príloha prováděcího nařízení Komise (EU) č. 540/2011. Ústřední věstník Evropské unie z 15. 12. 2017, L333/10-L333/16.

[7] Obnovení schválení účinné látky glyfosát. Usnesení Evropského parlamentu ze dne 13. dubna 2016 o návrhu prováděcího nařízení Komise, kterým se v souladu s nařízením Evropského parlamentu a Rady (ES) Č. 1107/2009 o uvádění prípravků na ochranu rostlin na trh obnovuje schválení účinné látky glyfosát a mění príloha prováděcího nařízení (EU) Č. 540/2011 (2018/C 058/11). Ústřední věstník Evropské unie z 15. 2. 2018, C58/102-C58/108.

[8] VRANA, B., ALLAN, I.J., GREENWOOD, R., et al. Passive sampling techniques for monitoring pollutants in water. Trends in Analytical Chemistry, 2005, Vol. 24, No. 10, p. 845-868.

[9] CLAUDE, B., BERHO, C., BAYOUDH, S., et al. Preliminary recovery study of a commercial molecularly imprinted polymer for the extraction of glyphosate and AMPA in different environmental waters using MS. Environ. Sci. Pollut. Res., 2017, 24, 12293-12300.

[10] SCHAEFER, M. and JOHNSON, M.L. Pharmaceuticals and personal care products in the Sacramento river. University of California, Davis, USA, October 2019.

[11] PCB a jejich odpady. EnviWeb (on-line). Dostupné z: http://www.enviweb.cz/17176

[12] AHRENS, L., DANESHVAR, A., LAU, A.E., and KREUGER, J. Characterization of five passive sampling devices for monitoring of pesticides in water. Journal of Chromatography, 2015, A, 1405, p. 1-11.

[13] BERHO, C., CLAUDE, B., COISY, E., et al. Laboratory calibration of a POCIS-like sampler based on molecularly imprinted polymers for glyphosate and AMPA sampling in water. Anal. Bioanal. Chem.. 2017, 409, p. 2029-2035.

\section{Autoři}

Ing. Tomáš Mičaník, Ph.D. ${ }^{1}$

凶tomas.micanik@vuv.cz

Ing. František Sýkora'

凶frantisek.sykora@vuv.cz

\section{Ing. David Chrastina ${ }^{1}$}

凶david.chrastina@vuv.cz

\section{Ing. Nikola Cielecká'}

凶nikola.cielecka@vuv.cz

Ing. Veronika Kucharczyková ${ }^{1}$

凶veronika.kucharczykova@vuv.cz

\section{Ing. Alena Kristová}

凶alena.kristova@vuv.cz

\section{Ing. Tomáš Ocelka, Ph.D. ${ }^{2}$}

凶tomas.ocelka@ehss.eu

\section{Ing. Jiří Oceánský}

凶jiri.oceansky@ehss.eu

'Výzkumný ústav vodohospodářský T. G. Masaryka, v. v. i.

${ }^{2}$ E\&H services, a. s.

Příspěvek prošel lektorským řízením. 


\section{SPACE-TIME DYNAMIC OF PESTICIDE LOADING IN THE DRINKING WATER RESERVOIR ŠVIHOV}

\section{MICANIK, T.'; SYKORA, F.'; CHRASTINA, D.'; \\ CIELECKA, N. ${ }^{1} ;$ KUCHARCZYKOVA, V.'; \\ KRISTOVA, A.; OCELKA, T. ${ }^{2}$; OCEANSKY, J. ${ }^{2}$}

'TGM Water Research Institute, p.r.i.

${ }^{2} \mathrm{E} \& \mathrm{H}$ services, a. $\mathrm{s}$.

Keywords: surface water - passive sampling water reservoir Švihov - pollution - pesticides

The article deals with space-time dynamic of non-polar and polar compounds load into the drinking water reservoir Švihov in Želivka river basin during the whole vegetation season by passive sampling techniques. The monitoring on the nine tributaries of the Švihov water reservoir and on the raw water inlet to the Želivka drinking water treatment plant took place for eight months from April to November 2018. Several types of membranes were used to capture wide range of pollutants: silicone rubber (61 compounds measured), semipermeable membrane device (43 compounds measured) and polar organic chemical integrative sampler (38 compounds measured). Exposition time in water environment was 30 days. Hydrological and precipitation data from measuring stations in Želivka river catchment were recorded.

Several dozens of organic compounds (over 80 ) were detected by passive monitoring. Presence of formerly widely used organochlorine pesticides $\mathrm{HCH}$ and DDT were confirmed. The ratio of PCB congeners in samples corresponds to historical usage of products containing Delor 106. The detection of pesticides in membranes corresponded to the species composition of cultivated agricultural crops in the catchments of individual tributaries. The level of water pollution depended strongly on precipitation-runoff conditions, soil erosion and river basin characteristics. The most polluted were Medulán and Lohenický streams. For some pesticides the metabolite concentrations were higher than parent compound concentration. The highest levels of pesticides were observed for metazachlor (19,000 ng/membrane), metolachlor (max. 1,300 ng/ membrane) and terbuthylazine-2-hydroxy (1,800 ng/membrane). Of the nonpolar compounds, the highest concentration was found for fluoranthene (683 ng/ membrane). 